\title{
PENYERAPAN LOGAM BERAT (Pb) OLEH LIMBAH KULIT JENGKOL (Pithecellobium jiinga) \\ ${ }^{1}$ Merry Thressia \\ ${ }^{1}$ Staf Pengajar Akademi Teknik Gigi Padang
}

\begin{abstract}
ABSTRAK
Logam berat di lingkungan perairan telah diketahui dapat menyebabkan beberapa kerusakan pada kehidupan air. Logam $\mathrm{Pb}$ banyak terdapat dalam limbah yang mencemari perairan. Pada kehidupan modern sekarang ini banyak masyarakat mempunyai kebiasaan membuang sampah disembarang tempat. Pemanfaatan serbuk kulit jengkol yang merupakan limbah organik yang berserakan di pasar tradisional dapat digunakan untuk pengolahan limbah cair yang mengandung logam $\mathrm{Pb}$.

Penelitian ini menggunakan metode eksperimen dengan menggunakan alat Spektrofotometer Serapan Atom yang kemudian dianalisis secara statistik menggunakan uji ANOVA dua arah tanpa interaksi.

Dari hasil penelitian didapatkan bahwa serbuk kulit jengkol dapat menyerap logam $\mathrm{Pb}$ yang ada didalam limbah cair yang ada di lingkungan sekitar.Setelah dilakukan uji statistik dengan uji ANOVA dua arah tanpa interaksi, penyerapan logam $\mathrm{Pb}$ oleh serbuk kulit jengkol dengan perbandingan $\mathrm{pH}$ dan massa, maka didapatkan nilai $\mathrm{F}$ hitung (massa) $=3,763$ dan nilai $\mathrm{F}$ tabel $=98,50$ sedangkan nilai $\mathrm{F}$ hitung $(\mathrm{pH})=0,812$ dengan nilai $\mathrm{F}$ tabel $=99,00$ dengan hasil $\mathrm{Ha}$ ditolak dan $\mathrm{H}_{0}$ diterima. Dari hasil penelitian ini dapat disimpulkan bahwa tidak ada perbedaan berarti dalam penyerapan logan $\mathrm{Pb}$ menggunakan serbuk kulit jengkol dalam variasi $\mathrm{pH}$ dan massa.
\end{abstract}

Kata kunci : Kulit Jengkol (pithecellobium jiringa), logam $\mathrm{Pb}, \mathrm{pH}$, adsorbsi.

\section{ABSTRACT}

Heavy metals in aquatic environments have been known to cause some damage to aquatic life. $\mathrm{Pb}$ metal is found in waste that pollute the waters. In modern life today many people have a habit of disposing of garbage disembarang place. Utilization of jengkol skin powder which is organic waste scattered in the traditional market can be used for the processing of liquid waste containing $\mathrm{Pb}$ metal.

This research used experimental method by using Atomic Absorption Spectrophotometer which then analyzed statistically using two way ANOVA test without interaction.

From the results of the study found that jengkol skin powder can absorb $\mathrm{Pb}$ metal that exists in the liquid waste in the surrounding environment. After statistical test with two-way ANOVA test without interaction, $\mathrm{Pb}$ metal absorption by jengkol skin powder with $\mathrm{pH}$ and mass ratio, then got value of $\mathrm{F}$ count (mass) $=3,763$ and $\mathrm{F}$ value table $=98,50$ while $\mathrm{F}$ value count $(\mathrm{pH})=0,812$ with value $\mathrm{F}$ table $=99,00$ with result Ha rejected and $\mathrm{H} 0$ accepted. From the results of this study can be concluded that there is no significant difference in the absorption of $\mathrm{Pb}$ logan using jengkol skin powder in $\mathrm{pH}$ and mass variations.

Keywords: SkinJengkol(pithecellobium jiringa), metal metal $\mathrm{Pb}, \mathrm{pH}$, adsorption.

\section{PENDAHULUAN}


Pencemaran air yaitu masuknya mahluk hidup, zat, energi atau komponen lain ke dalam air, sehingga kualitas air turun sampai ketingkat tertentu yang menyebabkan air tidak berfungsi sesuai dengan kegunaannya. Menurut Kristanto (2002:71) pencemaran air adalah penyimpangan sifat sifat air dari keadaan normal. Air dapat tercemar oleh komponen-komponenanorganik, diantaranya berbagai logam berat yang berbahaya.

Komponen-komponen logam berat ini berasal dari kegiatan industri yang melibatkan penggunaan logam berat antara lain industri tekstil, pelapisaan logam, cat/tinta warna, percetakan, bahan agrokimia dan lain-lain. Beberapa logam berat ternyata telah mencemari air melebihi batas yang berbahaya bagi kehidupan ( Wisnu,1995: 74).

Adanya logam berat dalam lingkungan perairan telah diketahui dapat menyebabkan beberapa kerusakan pada kehidupan air. Penggunaan hasil pertanian dan limbahnya sebagai penyerap logam berat dan senyawa beracun telah mendapat perhatian khusus dan telah banyak material-material yang diuji seperti kulit kacang, sekam padi, sabut kelapa, dan serbuk kulit jengkol.

Jengkol adalah tanaman yang memiliki buah dengan bau yang khas. Jengkol sering kali dijadikan sebagai masakan yang khas, sehingga banyak masyarakat menggilainya. Namun adapula masyarakat yang tidak menyukai aroma khasnya.

Kulit jengkol tergolong limbah organik yang berserakan dipasar tradisional dan tidak memiliki nilai ekonomis. Sampah organik ini mengotori lingkungan, sehingga belum termanfaatkan. Selama ini orang hanya memanfatkan buah jengkol hanya untuk dikonsumsi, tidak banyak orang yang mengetahui bahwa kulit jengkol juga banyak menyimpan manfaat salah satunya sebagai penyerap logam.

Logam $\mathrm{Pb}$ banyak terdapat dalam limbah yang mencemari perairan. Pada kehidupan yang modern ini banyak masyarakat mempunyai kebiasaan membuang sampah tidak pada tempatnya.

$\mathrm{Pb}$ dan persenyawaannya dapat berada di dalam perairan secara alamiah dan sebagai dampak dari aktivitas manusia. Secara alamiah, $\mathrm{Pb}$ dapat masuk kebadan perairan melalui pengkristalan $\mathrm{Pb}$ di udara dengan bantuan air hujan. Di samping itu,proses korosifikasi dari bantuan mineral akibat hempasan gelombang dan angin, juga merupakan salah satu jalur sumber $\mathrm{Pb}$ yang akan masuk kedalam badan perairan.

$\mathrm{Pb}$ yang masuk ke dalam perairan sebagai dampak dari aktifitas kehidupan manusia ada bermacam bentuk. Diantaranya adalah: air buangan (limbah) dari industri yang berkaitan dengan $\mathrm{Pb}$, air pembuangan dari pertambangan biji timah hitam dan hasil pembuangan sisa industri mebel. Buangan-buangan tersebut akan jatuh pada jalur-jalur perairan seperti anak-anak sungai untuk kemudian akan dibawa terus menuju lautan. Umumnya jalur buangan dari bahan sisa perindustrian yang menggunakan $\mathrm{Pb}$ akan merusak tata lingkungan perairan yang dimasukinya (menjadikan sungai dan alurnya tercemar).

Penelitian ini dilakukan untuk melihat pengaruh $\mathrm{pH}$ dan massa limbah kulit jengkol (Pithecellobium Jiringa) dalam menyerap logam Timbal $(\mathrm{Pb})$, sehingga dari hasil penelitian ini dapat diketahui berapa kemampuan serbuk kulit jengkol dapat menyerap logam $\mathrm{Pb}$ di lingkungan perairan.

\section{BAHAN DAN METODA}

Sampel yang digunakan dalam penelitian ini adalah limbah kulit jengkol, larutan induk $\mathrm{Pb}, \mathrm{HNO}_{3}$, $\mathrm{NaOH} 4 \mathrm{~N}$, HCL $0,1 \mathrm{~N}$ dan aquabides.Alat yang dipakai dalam penelitian ini adalah Spektrofotometer Serapan Atom, peralatan gelas, neraca analitik, hot plate, labu ukur ( $250 \mathrm{~mL}$ dan $50 \mathrm{~mL}$ ), ayakan 10 mesh.

Limbah kulit jengkol sebanyak $1 \mathrm{~kg}$ di jemur, kemudian dihaluskan dengan blender, dan diayak dengan ayakan mesh 10 ukuran $2 \mathrm{~mm}$. Kemudian dibedakan masing-masing 5 gram, dan 15 gram. Untuk mengukur kadar airnya, serbuk kulit jengkol ditimbang dalam cawan penguap yang telah diketahui bobot konstannya seberat 2,000 gram. Kemudian dimasukkan kedalam oven pada suhu $105^{\circ} \mathrm{C}$ selama 1 jam dan didinginkan dalam desikator selama 10 menit. 
Hasilnya kemudian ditimbang dengan neraca analitik, dan dicatat bobot yang diperoleh, sehingga dapat dihitung bobot konstan dari serbuk kulit jengkol.

Untuk mengetahui banyaknya serapan logam, serbuk kulit jengkol ditimbang sebanyak 5 gram, dan 15 gram. Kemudian tambahkan kolom kromatografi masing-masing sebanyak 5 gram, , dan 15 gram.

Selanjutnya diambil $100 \mathrm{ml}$ larutan $\mathrm{Pb} 100$ ppm dengan $\mathrm{pH} 3$ pada gelas ukur $100 \mathrm{ml}$, dan masukan larutan tersebut kedalam kolom kromatografi dengan masing-masing berat absorban yang ditimbang. (perlakuan yang sama pada larutan logam $\mathrm{Pb} 100$ ppm dengan $\mathrm{pH} 7$ dan $\mathrm{pH}$ 10).Hasil saringan ditampung dengan gelas piala $250 \mathrm{ml}$.

Selanjutnya tambahkan $2 \mathrm{ml} \mathrm{HNO}_{3}$ pekat kedalam masing-masing hasil saringan tadi dan beri kode pada masing-masing botol sampel. Hasil saringan di ukur adsorbannya dengan Spektrofotometer Serapan Atom pada panjang gelombang 283,7 nm.

\section{HASIL DAN PEMBAHASAN}

Tabel 4.1 Konsentrasi Penyerapan Logam Pb oleh Serbuk Kulit Jengkol

\begin{tabular}{|c|l|c|c|}
\hline $\begin{array}{l}\text { Kens. } \\
\text { Massa }\end{array}$ & pH 3 & pH 7 & pH 10 \\
\hline $5 \mathrm{~g}$ & 79,66 & 94,946 & 86,015 \\
\hline $15 \mathrm{~g}$ & 98,421 & 97,073 & 93,611 \\
\hline
\end{tabular}

Nilai Table

a) $\mathrm{F} 1<(1 \% ; 1 ; 2)=\mathrm{F} 1<98,50$

b) $\mathrm{F} 2<(1 \% ; 2 ; 2)=\mathrm{F} 2<99,00$

Serbuk kulit jengkol memiliki kemampuan dalam menyerap logam berat, seperti logam $\mathrm{Pb}$. Serbuk kulit jengkol sebagai adsorben diasumsikan mengandung selulosa dimana pada selulosa terdapat situs aktif yang mampu mengikat ion logam. Selain itu, serbuk kulit jengkol juga mempunyai pori-pori yang dapat menjebak ion logam berat.

Percobaan penyerapan logam berat $\mathrm{Pb}$ oleh serbuk kulit jengkol dilakukan dengan menggunakan larutan umpan $\mathrm{PbNO}_{3}$ dengan konsentrasi 100 ppm. Caranya larutan $\mathrm{PbNO}_{3}$ sebanyak $100 \mathrm{ml}$ dimasukkan kedalam 6 kolom yang berisi serbuk kulit jengkol dengan berat 5 gram dan 15 gram dengan variasi $\mathrm{pH} 3,7$ dan 10 . Kemudian dilakukan penyaringan, hasil saringan didestruksi kemudian di baca dengan Spektrofotometer Serapan Atom.

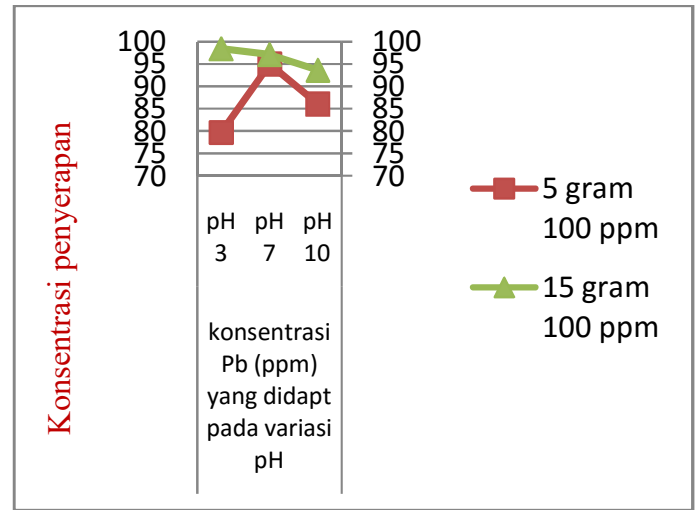

Grafik 4.1 hubungan massa serbuk dan $\mathrm{pH}$ terhadap penyerapan logam $\mathrm{Pb}$ 
Dari grafik 4.1 diatas terlihat bahwa berat serbuk kulit jengkol mempengaruhi penyerapan logam. Semakin berat serbuk kulit jengkol, semakin besar penyerapannya. Penyerapan logam dengan massa 15 gram lebih tinggi dibandingkan dengan massa 5 gram. Hal ini terjadi karena dengan semakin bertambah jumlah serbuk kulit jengkol menyebabkan bertambahnya jumlah partikel dan luas permukaan material serbuk kulit jengkol, sehingga menyebabkan semakin bertambah besarnya daya serap terhadap $\mathrm{Pb}$.

Namun tidak terdapat pengaruh $\mathrm{pH}$ dalam penyerapan logam oleh serbuk kulit jengkol, hal ini dapat dilihat dari rata-rata penyerapan logam $\mathrm{Pb}$ didapatkan rata-rata penyerapan logam $\mathrm{Pb}$ pada $\mathrm{pH} 3$ dengan konsentrasi logam $\mathrm{Pb}$ yang terserap 89,040 ppm, pada $\mathrm{pH} 7$ sebanyak 96,009, dan $\mathrm{pH} 10$ sebanyak 89,813 ppm.

Penyerapan logam terbesar terjadi pada $\mathrm{pH}$ netral. Hal ini dikarenakan terjadi adsorbsi yaitu proses yang terjadi ketika suatu cairan terikat pada suatu padatan (serbuk kulit jengkol) dan membentuk suatu lapisan tipis pada permukaanya saja. berbeda dengan absorbsi yang penyerapan cairannya dengan membentuk suatu larutan.

Setelah dilakukan uji statistik dengan uji ANOVA dua arah tanpa interaksi, penyerapan logam $\mathrm{Pb}$ oleh serbuk kulit jengkol dengan perbandingan $\mathrm{pH}$ dan massa, maka didapatkan nilai $\mathrm{F}$ hitung $($ massa) $=3,763$ dan nilai $\mathrm{F}$ tabel $=98,50$ sedangkan nilai $\mathrm{F}$ hitung $(\mathrm{pH})$ $=0,812$ dengan nilai $\mathrm{F}$ tabel $=99,00$ dengan hasil $\mathrm{Ha}$ ditolak dan $\mathrm{H}_{0}$ diterima. Berarti dapat disimpulkan bahwa tidak ada perbedaan berartipenyerapan logan $\mathrm{Pb}$ menggunakan serbuk kulit jengkol dalam variasi $\mathrm{pH}$ dan massa.

Dari hasil yang telah didapatkan, hal ini membuktikan bahwa serbuk kulit jengkol dapat menyerap logam $\mathrm{Pb}$ yang ada didalam limbah cair yang ada di lingkungan sekitar.

Serbuk kulit jengkol dapat menyerap logam $\mathrm{Pb}$ yang ada di larutan yang mengandung logam $\mathrm{Pb}$, berarti serbuk kulit jengkol juga dapat menyerap logam berat lainnya seperti $\mathrm{Cu}$, $\mathrm{Hg}, \mathrm{Fe}$, dan $\mathrm{Zn}$. Karena struktur kimia atom $\mathrm{Cu}, \mathrm{Hg}, \mathrm{Fe}$, dan $\mathrm{Zn}$ termasuk dalam logam berat bersama $\mathrm{Pb}$. Serbuk kulit jengkol yang selama ini dianggap sebagai limbah yang tidak berguna sekarang sudah bisa digunakan untuk mengurangi limbah cair yang mengandung logam berat.

\section{KESIMPULAN}

Setelah dilakukan uji statistik dengan uji ANOVA dua arah tanpa interaksi, penyerapan logam $\mathrm{Pb}$ oleh serbuk kulit jengkol dengan perbandingan $\mathrm{pH}$ dan massa, maka didapatkan nilai $\mathrm{F}$ hitung (massa) $=3,763$ dan nilai $\mathrm{F}$ tabel $=98,50$ sedangkan nilai $\mathrm{F}$ hitung $(\mathrm{pH})$ $=10,812$ dengan nilai $\mathrm{F}$ tabel $=99,00$ dengan hasil $\mathrm{Ha}$ ditolak dan $\mathrm{H}_{0}$ diterima. Berarti dapat disimpulkan bahwa tidak ada perbedaan berarti penyerapan logan $\mathrm{Pb}$ menggunakan serbuk kulit jengkol dalam variasi $\mathrm{pH}$ dan massa.

Dari hasil penelitian yang telah diuraikan diatas, maka didapat kesimpulan sebagai berikut:

a) Serbuk kulit jengkol dapat menyerap logam $\mathrm{Pb}$

b) Tidak ada pengaruh signifikan penyerapan logam $\mathrm{Pb}$ dalam variasi massa serbuk kulit jengkol

c) Tidak ada pengaruh signifikan penyerapan logam $\mathrm{Pb}$ oleh serbuk kulit jengkol dengan variasi $\mathrm{pH}$ larutan.

\section{DAFTAR PUSTAKA}

Kristianto, P. 2002. Ekologi Industri. Penerbit ANDI. Yogyakarta. 
Taberima, S., 2004. Peranan Mikroorganisme Dalam Mengurangi Efek Toksik Pada Tanah Terkontaminasi Logam Berat. Program Pascasarjana / S3 / Institut Pertanian Bogor, Bogor.

Tjitrosoepomo, G. (2000). Taksonomi Tumbuhan (Spermatophyta). Yogyakarta: Gadjah Mada University Press. Hal. 192-206

Wisnu A Wardhana. 1995. Dampak Pencemaran Lingkungan. Yogyakarta: Penerbit Andi 